UDC 621.45.018.2

Doi: 10.31772/2587-6066-2020-21-1-62-69

For citation: Begishev A. M., Zhuravlev V. Y., Torgashin A. S. Features and modernization methods of thrust measurement devices for liquid rocket engine test stands. Siberian Journal of Science and Technology. 2020, Vol. 21, No. 1, P. 62-69. Doi: 10.31772/2587-6066-2020-21-1-62-69

Для цитирования: Бегишев А. М., Журавлев В. Ю., Торгашин А. С. Особенности и возможный путь модернизации силоизмерительных устройств испытательных стендов жидкостных ракетных двигателей // Сибирский журнал науки и технологий. 2020. Т. 21, № 1. С. 62-69. Doi: 10.31772/2587-6066-2020-21-1-62-69

\title{
FEATURES AND MODERNIZATION METHODS OF THRUST MEASUREMENT DEVICES FOR LIQUID ROCKET ENGINE TEST STANDS
}

\author{
A. M. Begishev", V. Y. Zhuravlev, A. S. Torgashin \\ Reshetnev Siberian State University of Science and Technology \\ 31, Krasnoyarsky Rabochy Av., Krasnoyarsk, 660037, Russian Federation \\ *E-mail alex-beg95@mail.ru
}

\begin{abstract}
During the liquid rocket engines (LRE) testing, direct thrust measurement is carried out using thrust measurement devices. The aim of the work was, on the basis of existing data from the theory of tests and test stands devices, to highlight the design features of the thrust measurement devices and propose an option to improve the performance of this stand system. The work considers the basic circuit power schemes of thrust measurement devices by the example of power measuring systems of existing fire test stands and the features of work on preparing systems for testing. The types of calibration systems worked out in practice, their advantages and disadvantages, which constitute calibration errors, are considered. An option is proposed to modernize thrust measurement devices, in particular, through implementing of an electromechanical drive based on a planetary roller-screw mechanism as a force setting element into the calibration system. A possible general conceptual diagram of the power drive operation as a part of the calibration system of the thrust measurement devices is given. The advantages and disadvantages, the predicted effects of implementation are considered.

A more detailed analysis of this proposal may serve as an occasion for the modernization of the specific operational thrust measurement devices design at the fire test stand for LREs or may be a working option when designing a new thrust measurement device.
\end{abstract}

Keywords: fire test stand, thrust measurement device, calibration system, electromechanical drive.

\section{ОСОБЕННОСТИ И ВОЗМОЖНЫЙ ПУТЬ МОДЕРНИЗАЦИИ СИЛОИЗМЕРИТЕЛЬНЫХ УСТРОЙСТВ ИСПЫТАТЕЛЬНЫХ СТЕНДОВ ЖИДКОСТНЫХ РАКЕТНЫХ ДВИГАТЕЛЕЙ}

\author{
А. М. Бегишев ${ }^{*}$, В. Ю. Журавлев, А. С. Торгашин \\ Сибирский государственный университет науки и технологий имени академика М. Ф. Решетнева \\ Российская Федерация, 660037, г. Красноярск, просп. им. газ. «Красноярский рабочий», 31 \\ E-mail alex-beg95@mail.ru
}

\begin{abstract}
В процессе испытания жидкостных ракетных двигателей (ЖРД) прямое измерение тяги осуществляется с помощью силоизмерительных устройств (СИУ). Целью работы было на основе существующих данных из теории огневых испытаний и устройств испытательных стендов выделить особенности конструкиий СИУ и предложить вариант по улучшению работы данной стендовой системы. В работе рассмотрень основные принципильные силовые схемы СИУ на примере силоизмерительных систем действующих огневых испытательных стендов ЖРД, а также рассмотрены особенности работ по подготовке системы силоизмерения $\kappa$ испытанию. Рассмотрены типы отработанных в практике градуировочных систем, их достоинства и недостатки, составляющие погрешности градуировки. Предложен вариант модернизации СИУ, в частности, внедрение в градуировочную систему в качестве силозадающего элемента электромеханического привода на базе планетарного ролико-винтового механизма (ПРВМ). Приведена возможная общая концептуальная схема работы силового привода в составе градуировочной системы СИУ. Рассмотрень достоинства и недостатки, прогнозируемые эффекты внедрения.

Более детальный анализ данного предложения может послужить поводом для модернизации конструкции того или иного конкретного действующего СИУ на огневом стенде испытания ЖРД или же явиться рабочим вариантом при проектировании нового СИУ.
\end{abstract}

Ключевые слова: испытательный стенд ЖРД, силоизмерительное устройство, градуировочная система, электромеханический привод. 
Introduction. The rapid development of rocket and space technology entails the emergence of features that directly influence the reliability of the product at all stages of its life cycle. One of the most important final stages of serial or prototype production is the stage of rocket and space equipment ground testing. This stage of production makes it possible to determine the quantitative and (or) qualitative characteristics of a product, to assess the correctness of the adopted technical solutions in the design and manufacturing process, as well as to identify the type and the nature of product destruction in the event of an emergency test output.

The LREs and their units undergo ground testing at various stages of production but firing tests (i.e. the process of an engine comprehensive simulation) are the final and determining type of tests. The purpose of static firing tests is autonomous engine testing and in the case of flight firing tests all systems of the aircraft on which the engine is installed are checked [1].

The cost of the flight and static firing tests varies widely hence, flight tests are only the final stage of prototype development and the final conclusion on the compliance of this LRE construction with technical specifications and its suitability for serial production is given based on the test results [2]. The stage of firing tests represents a large amount of tests that the engine undergoes during the design and manufacturing process and therefore, the stage includes a whole range of questions: from the decision to adjust the design of the prototype engine during development tests to ensure output quality control of serial products.

Firing tests are carried out at the test complex using the specialized firing test stands equipped with the systems providing: simulation of object test conditions, test stands and product objects control, as well as testing results measurement and recording. During the test continuous registration of many physical parameters is carried out and all stand systems must be in well-functioning operation for its implementation. Stand systems are required to guarantee high reliability and measurement accuracy. No less important is the requirement for the technological effectiveness of stand systems which can include the quality and complexity of the preparatory work carried out before the test, as well as routine maintenance included in the scheduled outage.

Features of LRE thrust measurement. The thrust of a liquid rocket engine is one of the most important parameters to evaluate the engine characteristics. As is well known, the thrust of the engine chamber is the resultant of hydrogasdynamic forces acting on the inner surfaces of the chamber upon expiration of matter and environmental pressure forces acting on the chamber outer surfaces, with the exception of external aerodynamic drag forces [3]. This resulting force causes the movement of the apparatus, on which the engine is set. According to the definition, this kind of thrust force calculation is complicated and not quite accurate since it is necessary to know the law of pressure change along the entire length of the chamber which, especially on the tapering part of the nozzle (i.e. from the end of the combustion chamber to the critical section) is not always known. Hence, a reliable indicator of the engine thrust value can only be deter- mined by directly measuring the engine thrust on a test stand. During the test high demands are made on the accuracy of its measurement: the permissible error in most cases should not exceed $0.3-0.5 \%$ of the nominal value [4].

It is worth noticing that the focus of direct thrust measurement comes from both the type and class of the engine as well as the ability of the stand to create simulating conditions for the engine to work in the design mode. For powerful engine testing the stand design providing a vertical arrangement of the engine axis is the most appropriate. But the stand designs including thrust measurement systems for the horizontal location of tested engines are also known. For direct thrust measurement on the test stands a special force measurement system is used which includes specialized information transition channels and thrust measurement devices consisting of the following structural units: a machine, a calibration system and a measuring system (force transducers, displacement sensors).

Basic circuit power schemes of the thrust measurement devices. The design of the thrust measurement devices is a combination of the three above mentioned components but a fundamental difference is implied by the choice of the device circuit power scheme, i. e. a type of machine and a calibration system. The machine consists of two main elements: a stationary base and a frame to which the tested engine is mounted. Thus, the principle of interaction between the thrust measurement devices can be represented by the scheme shown in fig. 1 . The frame which can be moveable or stationary perceives the thrust from the tested engine and transfers it to the measuring system and base. Depending on the design machines are divided into four groups: machines with elastic bonds between the stationary base and the moving frame, rigid machines, machines with minimal friction and special machines [5].

The calibration system with respect to the measuring system is intended for its verification and calibration. Choosing the type of calibration system as well as the hardware version depends on the machine design used for the thrust measurement devices. There are several calibration systems used at the test stands for powerful RLEs: a hydraulic calibration system, a lever-operated calibrate system.

During the LRE tests the scheme of the thrust measurement devices for the machine with elastic bonds between the stationary base and the moving frame is mostly common since this scheme is easily integrated with all the main calibration systems. With this scheme the movable frame is usually hanged to the frame with strip suspension or flexible joints.

The first example of this circuit power scheme implementation is the thrust measurement devices of the stand № 1 manufactured by the "Testing and Refueling complex" (JSC Krasmash). The thrust measurement devices are a combination of the level-operated calibrate system and the double-support machine with elastic bonds between the frame and the stationary base, the principle scheme is shown in fig. 2. According to this system design the stationary part is represented by two racks 1 , mounted on the overlap between the fire compartment 
(where the tested engine is installed) and the thrust measurement devices compartment where the measuring and calibration systems are located. 3-pin-springs 5 are used as elastic bonds, while the external petals of the springs are connected to the stationary part and the internal ones are linked to the movable part of the machine. The feed lines are taken and fixed to the stand frame. The product is mounted to the transition frame 4. If necessary, the movable part of the machine is locked relatively the stationary one using eighth locking screws 6 . Force transducers 7 are installed on the adjusting inserts 8 between the stationary and movable parts of the machine and measure the impact force of the moving part. The signal generated by the force transducers is transmitted through special communication channels to the complex of measuring and computing and information-measuring systems. Two force transducers are installed on each machine support. In this case, each pair of force transducers is of the same type and duplicate.

The lever-operated calibration system consists of upper levers 11,12 and lower levers 9, 10. The lower levers of the second kind, with a gear ratio of $i \approx 3.6$ are connected to the frame using rods 13 and to short arms of the upper levers using tenders 14 . The upper levers of the first kind with a gear ratio of $i \approx 14$, rest upon fixed racks 15 . Suspensions 16 are fixed on the long arms of the lower levers. Calibration loads are manually placed on the suspensions, which affects the complexity of the process. All connections of the levers with the other parts of the leveroperated calibration system are carried out using prisms and caps. Such a connection provides a constant gear ratio during an operation.

The accuracy of this calibration system depends on rigidity, accuracy of the operated levers gear ratio as well as on the condition of the knife-edge supports surfaces, since they have increased wear under vibration loads.

The second example of a power circuit scheme including the machine with elastic bonds between the base and the movable frame, but with a hydraulic calibration system according to operation [6] are the thrust measurement devices of the stand test manufactured by the JSC NPO
Energomash named after academician V. Glushko. The principle scheme is presented in fig. 3 .

According to this thrust measurement system design, the fixed part is attached to the power ring 7 and includes: frames 4,5 ; brackets 11,12 ; a spacer 15 ; a hydraulic loader 13. The rest components form a movable part of the thrust measurement system. This movable part is connected to the base in transverse directions by means of tapes 18 and with the fixed part by means of springs 17 . The springs have great stiffness in the plane perpendicular to the axis of the engine and soft one in the plane parallel to the axis of the engine. This permits free motion of the non-stationary part relative to the stationary one in the direction of the engine axis. During the test the traction force from the engine is sequentially transmitted through frames $1,2,3$ to the force transducer 16 with the spacer 15 . The spacer, in turn, presses on the frame 4 . The frame 4 abuts against the frame clamps 5 and then against the power ring 7 .

Calibration is carried out using a special power hydraulic loader 13, which lengthening abuts against the frame 5 and the force transducer 9. During loading the frame 3 is moved using the frame 6 and rods 10 . With this "internal" loading the force ring 7 is not involved in the load perception.

The essence of creating the exact value of the calibration force, in this case, comes down to using an additional force transducer 9 and according to its testimony load and adjustment of the force developed by the hydraulic loading device is carried out. The hydraulic calibration system permits creating accurate force with remote control, which has a positive effect on the system technological effectiveness.

The group of rigid machines includes devices with a fixed frame. These machines are structurally the simplest and differ in minimum weight and overall dimension [5]. According to this scheme the force transducer is rigidly fixed to the supporting structure of the stand and the force is transmitted from the engine through a fixed frame i.e. a frame without any movable connection between the frame and the stationary base.

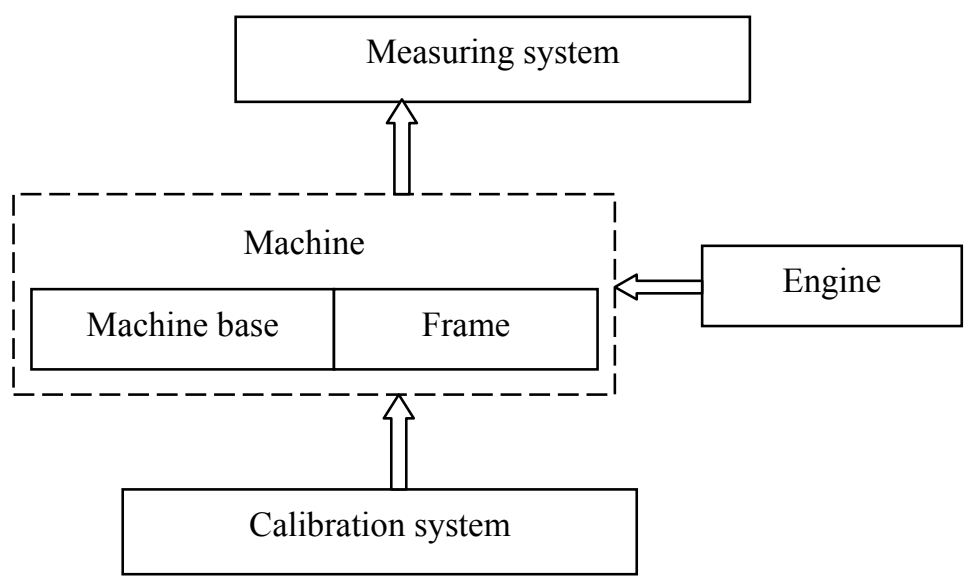

Fig. 1. Scheme of a test stand thrust measurement system for LREs

Рис. 1. Схема работы СИУ стенда испытаний ЖРД 


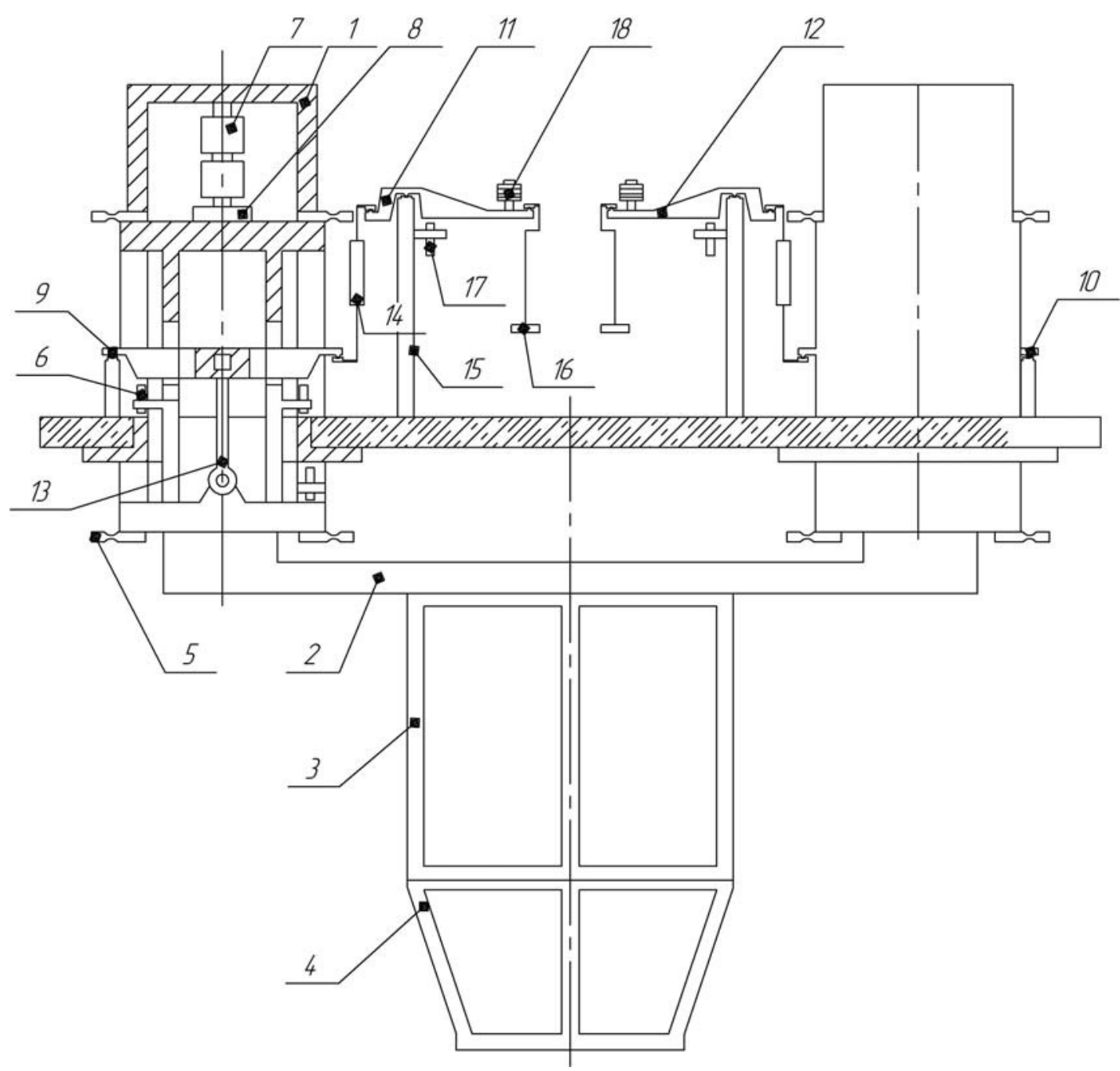

Fig. 2. Scheme of the thrust measurement system with a lever-operated calibrate system and the machine with elastic bonds between a frame and a stationary base:

1 - rack; 2 - frame; 3 - stand frame; 4 - transition frame; 5 - 3-pin-springs; 6 - locking screw; 7 - force transducer; 8 -adjusting insert; 9 - lever A1; 10 - lever A2; 11 - lever B1; 12 - lever B2; 13 - rod; 14 - tender; 15 - rack; 16 - suspension; 17 - screw; 18 - balancing load

Рис. 2. Схема СИУ с РГУ и станком с упругими связями между рамой и станиной:

1 - стойка; 2 - рама; 3 - рама стендовая; 4 - рама переходная; 5 - пружина Ш-образная; 6 - винт стопорный; 7 - силоизмеритель; 8 - вкладыш регулировочный; 9 - рычаг А1; 10 - рычаг А2; 11 - рычаг Б1; 12 - рычаг Б2; 13 - тяга; 14 - тендер; 15 - стойка; 16 - подвеска; 17 - винт; 18 - груз балансировочный

In this case, the thrust measurement devices may not have a calibration system provided that the dismantled force transducer is periodically calibrated in the measuring laboratory and then installed at the workplace. The scheme is common for testing the small thrust LREs. The practical example of this thrust measurement system scheme is a test stand for the LREs with a thrust of up to $20 \mathrm{kN}$ manufactured on the basis of the Aeronautics Institute of Technology in São José dos Campos, Brazil [7].

The group of machines with minimal friction includes machines in which the frame is moved with minimal friction, these are various kinds of rocking chairs, lunettes, trolleys. Currently, such machines are practically not used for the LRE testing. Whereas, when testing solid fuel rocket engines (SFRE) slipway equipment is widely used to orient and mount the SFRE on a test stand in horizontal position [8]. Examples of this scheme practical application are sources $[8 ; 9]$.

The fourth group of machines includes special devices that provide the ability to measure the LRE thrust whose structural features do not permit to test them on the above mentioned machines. For example, engines with nozzles located at an angle to the axis of the combustion chamber [5].

Revisiting the calibration of the trust measurement devices. Calibration is a technological operation which consists in obtaining a relationship between the values of the input measured parameter (in this case, the engine thrust force) and output informative parameter (depends on the type of sensor used). The calibration error, in turn, is the sum of systematic error of the means for setting the 
force, the random component of the error during calibration and the error of the recording device [10]. The systematic component of the basic error depends on the type and specific design of the calibration system. The random component of the error during calibration depends on the following factors: instability of external indicators of the calibration process (indoor air temperature, the tempera- ture of the thrust measurement devices), random collisions and vibration during calibration that cannot be eliminated, changes in the position of the force-setting elements.

Considering the main calibration systems and firing test stands used in the LRE thrust measurement system some of the features presented in table may be highlighted.

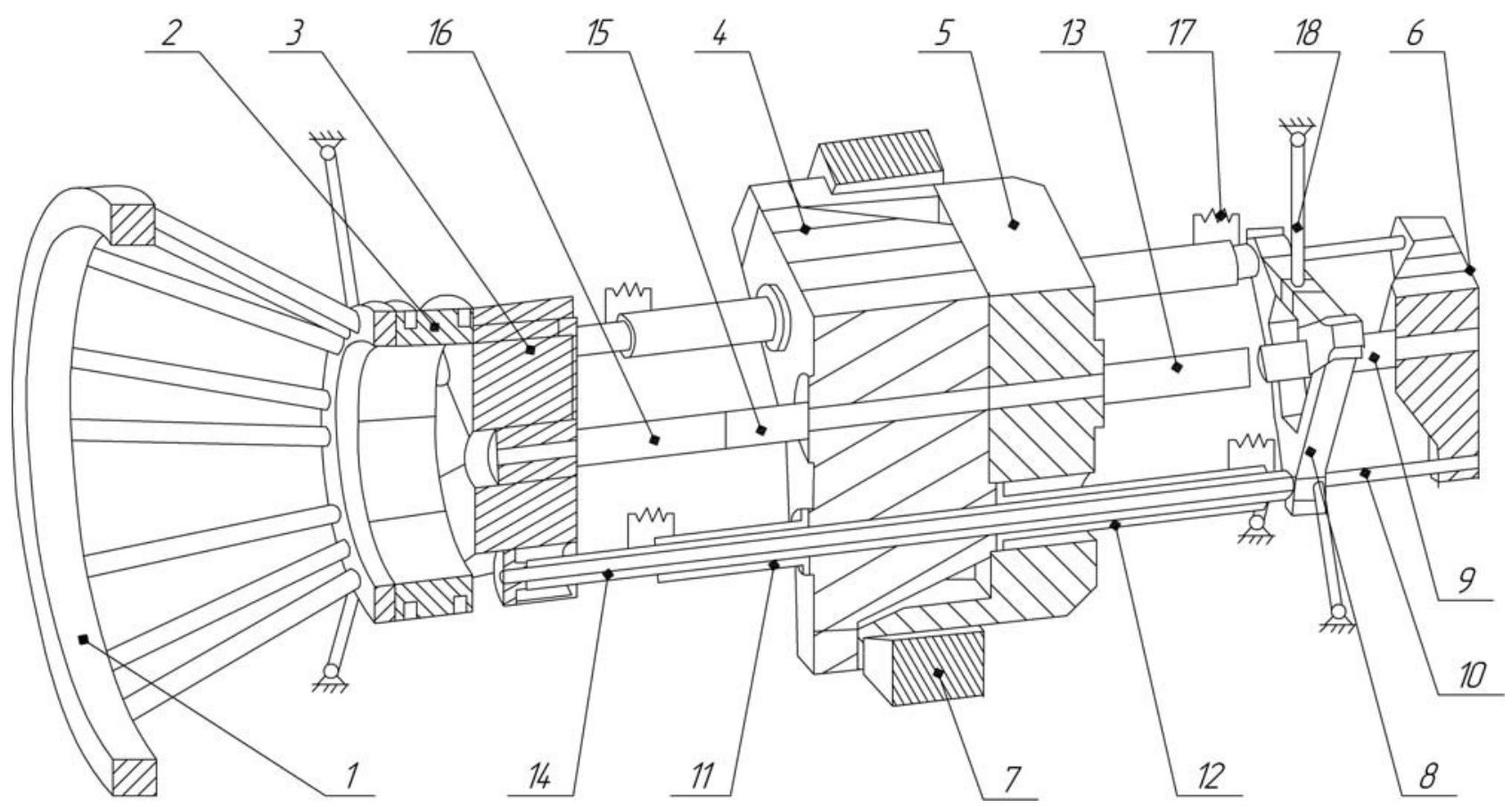

Fig. 3. Scheme of the thrust measurement system with a hydraulic calibration system and the machine with elastic bonds between the frame and the stationary base:

1-6-power-absorbing frames; 7 - power ring; 8 - a triangle; 9 - force transducer; 10 - calibration bar; 11,12 - bracket; 13 - hydraulic loader; 14 - movable bar; 15 - a spacer; 16 - force transducer; 17 - spring; 18 - tape (7 pieces)

Рис. 3. Схема СИУ с гидравлической градуировочной системой и станком с упругими связями между рамой и станиной: 1-6 - силовоспринимающие рамы; 7 - силовое кольцо; 8 - треугольник; 9 - силоизмеритель; 10 - градуировочная штанга; 11, 12 - кронштейн; 13 - гидронагружатель; 14 - подвижная штанга; 15 - проставка; 16 - силоизмеритель; 17 - пружина; 18 - лента (7 штук)

\section{Comparison table of calibration systems}

\begin{tabular}{|l|l|l|}
\hline \multicolumn{1}{|c|}{ Feature } & \multicolumn{1}{|c|}{ Lever-operated calibration system } & \multicolumn{1}{c|}{ Hydraulic calibration system } \\
\hline Calibration error & $\begin{array}{l}\text { Depends on the accuracy and value of the levers } \\
\text { gear ratio embedded in the design of a particular } \\
\text { device (the accuracy of gear ratios can reach } \\
0.01 \% \text { ), the accuracy of mounting prismatic sup- } \\
\text { ports, the accuracy of special loads }\end{array}$ & $\begin{array}{l}\text { Depends on the measurement error of the refer- } \\
\text { ence force transducers (reaches about 0.1\%), the } \\
\text { accuracy of the force-setting equipment }\end{array}$ \\
\hline Additional components & Special loads & Pumps, tanks, filters, valves, chokes, radiators etc. \\
\hline Maintenance required & $\begin{array}{l}\text { Periodic inspection and prophylactic replacement } \\
\text { of prisms and caps, verification of the lever gear } \\
\text { ratio, verification of the basic error when measur- } \\
\text { ing force by repeated calibration }\end{array}$ & $\begin{array}{l}\text { Checking and changing the oil, checking for } \\
\text { leaks, replacing filters, servicing additional } \\
\text { equipment, checking the basic error when measur- } \\
\text { ing force by repeated calibration }\end{array}$ \\
\hline $\begin{array}{l}\text { Correction of the cali- } \\
\text { bration step force } \\
\text { value }\end{array}$ & $\begin{array}{l}\text { Correction is not possible, the value of the calibra- } \\
\text { tion step is determined by the nominal mass of } \\
\text { special loads }\end{array}$ & $\begin{array}{l}\text { An additional reference force transducer is used } \\
\text { and according to its testimony the load is made } \\
\text { and the force is corrected }\end{array}$ \\
\hline Remote effort creation & Unavailable when using loads & Available \\
\hline Labor intensity & High & Low \\
\hline
\end{tabular}


To ensure more accurate thrust measurement readings the thrust measurement system calibration is carried out on the day of assigned test after the technological installation of the engine and connection of fuel lines and measuring pipelines, drain and purge lines, control and measurement systems cable trunks and all auxiliary fastening elements affecting the weight of the tested LRE. During the calibration process it is forbidden for workers to be in the stand or to perform work that may, in any way, affect the product.

A proposal for the thrust measurement systems modernization. The error of direct power LRE thrust measurement during the test consists of the measuring system (measuring components) error, calibration error, accuracy and completeness of various metrological characteristics when testing. These include several interference corrections: changes during the engine mass testing; changes in mass and temperature of the components; mismatch of the exemplary and measured effort points, the Bourdon effect and other phenomena affecting a particular thrust measurement system during the testing process [1]. With the development of computing technology one of the steps to modernize test systems was the implementation of new measurement and control systems on modern element bases to replace obsolete and wornout ones [11].

As a result of this lever and hydraulic calibration systems may be replaced for electric ones as a form of the thrust measurement system design modernization. It is proposed to use a special electromechanical drive based on a planetary roller-screw mechanism as a power drive to create the calibration force.

The electromagnetic drive is an electric cylinder with the mechanism that converts electrical energy into mechanical. The planetary roller-screw mechanism is used at law feed speeds and high forces. In this mechanism the load from the lead screw is transferred to the nut through the rounded sides of the rollers (force transmission through the satellite rollers). The disassembled planetary roller-screw mechanism is shown in fig. 4.

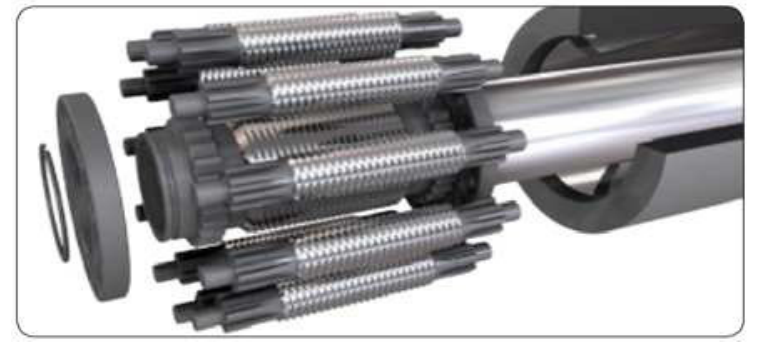

Fig. 4. Disassembled planetary roller-screw mechanism [12]

Рис. 4. ПРВМ в разобранном виде [12]

Consider principles of its operation. In contrast with the planetary gear drive in which satellite axis move in a plane normal to the axis of central wheel rotation, in the mechanism under consideration threaded rollers as satellites execute three motions. The rollers rotate around their axes; rotate around the axis of the screw together with the separators; rolling around the thread of the nut rollers move along the axis of the nut together with the screw [13]. The advantages as the basis for considering the im- plementation of this drive are the ability of the mechanism to work at high loads as well as the design simplicity and reliability which entails the simplification of the calibration device kinematic scheme. The electromechanical drive also allows remote control but unlike hydraulic systems it has a higher system response to the slightest changes and does not require the operation of additional equipment (as it is with hydraulic systems), only power and signal cables and a control unit are required for the electric cylinders operation. Electric cylinders are capable of operating at speeds of up to $1.5 \mathrm{~m} / \mathrm{s}$ with forces of up to $400 \mathrm{kN}$, they have a stroke of up to $1.2 \mathrm{~m}$ with positioning accuracy of approximately $1 \mu \mathrm{m}$ [14]. The use of electric cylinders as a force setting drive in the thrust measurement system is proposed to be carried out as it is shown in fig. 5.

Consider the case, when the maximum axial force created by the electromechanical drive is sufficient to calibrate the thrust measurement system. Depending on this system design the place of force application for measurement system calibration is determined. In the case of rigid machines or machines with elastic bonds between the frame and the stationary base the transmission of force set by the drive through the frame is meant. The system must include loading and control subsystems for functioning. Electric cylinders themselves are directly included in the loading subsystem and their number depends on the number of measurement branches and fixed supports of the thrust measurement machine. The control subsystem should include frequency and secondary converters, a strain gauge force transducer working on compression, power cables. To ensure operation the control subsystem should be integrated with the common stand control system. The value of the force created by the electric cylinder is entered in the PC software. And all the information about the amount of efforts is transmitted to the frequency converter through a processor module. The electric converter, in its turn, generates a supply voltage for the electric cylinder connected to it. The strain gauge force transducer is installed between the cylinder rod and the place of force application. Deformation of an elastic element causes imbalance of the strain gauge bridge. An electric unbalanced signal arrives at the secondary measurement converter for analog-to-digital conversion, and measured data processing and display [15]. Data on the actual force magnitude on the cylinder rod can ensure high accuracy of loading. The main error varies within errors of the primary and secondary transducers which can reach about $0.1 \%$ in the case of using a strain gauge transducer. In the case when thrust measurement devices include stands for testing powerful ERLs which thrust reaches $1000 \mathrm{kN}$ or more and when the electric cylinder maximum force is insufficient for calibration program a combination of the electromechanical drive and the leveroperated calibration system is proposed. The load from the electric cylinder is applied to a lever through which the increasing force is transmitted to the moving frame of the thrust measurement system.

As in the previous version, the work is carried out with electric voltage that is why this solution makes it possible to implement a stepless calibration method since the tasks of programming and force control are greatly simplified. 


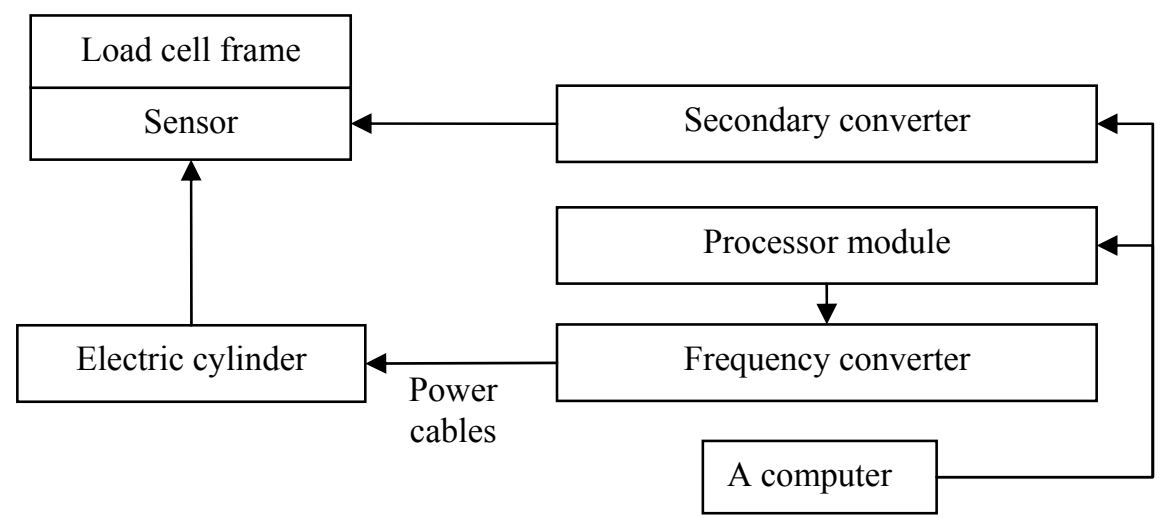

Fig. 5. Scheme of a calibration system based on an electromechanical drive

Рис. 5. Схема градуировочной системы на базе электромеханического привода

At the same time the remote control condition is fulfilled and this reduces the work complexity compared to standard calibration including the lever-operated calibration system. This scheme has inherent disadvantages of the lever calibration system in combination with advantages of the electric drive.

Electric cylinders have high efficiency (about $85 \%$ ) and the current consumption changes in proportion to the developed load. If it is necessary to minimize energy consumption the electric cylinders design permits graduated calibration since the electromagnetic brake is capable of holding the predetermined force. Whereas, the testing stand compartments have a category of increased fire hazard it is necessary to provide for explosion proof execution of operating elements to keep safe the electromechanical drive system.

Conclusion. Based on the theory of thrust measurement system design and practical use of thrust measurement devices on the LRE testing stands features, advantages and disadvantages of various principle thrust measurement system schemes were evaluated. A proposal is made for thrust measurement system modernization by implementating a calibration system based on the electromechanical drive. The general concept to use an electric cylinder as a calibration system loading device is presented. Disadvantages and prospects of implementing this drive into the calibration system of LRE firing test stands are estimated.

\section{References}

1. Yacunenko V. G., Nazarov V. P., Kolomencev A. I. Stendovye ispytaniya zhidkostnyh raketnyh dvigateley [Bench tests of liquid rocket engines: a training manual]. Krasnoyarsk, 2016, 248 p.

2. Kolomencev A. I., Kraev M. V., Nazarov V. P. Ispytanie i obespechenie nadezhnosti [Testing and ensuring reliability]. Krasnoyarsk, 2006, 336 p.

3. Vasil'ev A. P., Kudryavcev V. M., Kuznecov V. A. Osnovy teorii $i$ rascheta zhidkostnyh raketnyh dvigateley [Fundamentals of the theory and calculation of liquid rocket engines]. Moscow, Vyssh. Shkola Publ., 1983, 703 p.

4. Galeev A. G., Ivanov V. N., Katenin A. V. Metodologiya ehksperimental'noy otrabotki ZHRD $i$ DU, osnovy provedeniya ispytaniy $i$ ustrojstva ispytatel'nyh stendov [Methodology of experimental testing testing of LRE, the basics of testing and device test stand]. Kirov, MCNIP Publ., 2015, 436 p.

5. Zhukovskij A. E., Kondrusev V. S, Levin V. Ya. Ispytanie zhidkostnyh raketnyh dvigateley [Test of liquid rocket engines]. Moscow, Mashinostroenie Publ., 1981, $199 \mathrm{p}$.

6. Loshkarev A. N, Merzlyakov D. V., Milov A. E. [Calculated strength analysis of thrust-measuring device of stand for tests of rocket engines with a thrust of 1000 TF]. Trudy NPO Energomash im. akademika V. P. Glushko. 2012, No. 29. P. 311-327 (In Russ.).

7. Santos E. A., Alves W. F., Prado A. N. A. et al. Development of test stand for experimental investigation of chemical and physical phenomena in Liquid Rocket engine. Journal of Aerospace Technology and Management. 2011, P. 159-170. Doi: 10.5028/jatm.2011.03021111.

8. Vinickij A. M., Volkov V. T. Konstrukciya $i$ otrabotka RDTT [Design and testing of solid propellant rocket motors]. Moscow, Mashinostroenie Publ., 1980, P. 98-106.

9. Bol'shakov A. N., Zaval'nyuk A. G. Stend dlya izmereniya tyagi raketnogo dvigatelya [Stand for measuring propulsion of a rocket engin]. Patent RF, F 02 K 9/96, 2004.

10. Etkin L. G. Vibrochastotnye datchiki. Teoriya $i$ praktika [Vibration sensors. Theory and practice]. Moscow, Izd-vo MGTU im. N. E. Baumana Publ., 2004, 408 p.

11. Vinogradov V. A., Valov V. I. [Features of the preparation and conduct of fire and cold tests of liquid rocket engines at the Chemical Plant - a branch of OJSC "Krasmash"]. Reshetnevskie chteniya : materialy XIII Mezhdunar. nauch. konf. (10-12 noyabrya 2009, g. Krasnoyarsk) $v 2 \mathrm{ch}$. [International science and research conference (in memory of the Mikhail Fedorovich Redhetnev, general constructor of spase vehicles and rocket systems)]. Krasnoyarsk, 2009, P. 102-103.

12. SKF compact inverted roller screw. Available at: https://www.skf.com/binary/77-68546/10592-EN_ compact-inverted-roller-screw.pdf (accessed: 29.01.2020).

13. Ryakhovsky O. A., Vorobyov A. N., Marokhin A. S. [Planetary roller-screw mechanism for convert- 
ing rotational motion into translational, made according to the "Inverted" scheme]. News of higher educational institutions. Mechanical engineering. 2013, No. 9, P. 44-48.

14. Nauchno-proizvodstvennoe predpriyatie MERA [Scientific-Production Enterprise MERA]. Available at: http://nppmera.ru/npp-mera-peredovyie-resheniyadlya-staticheskix-ispyitanij (accessed: 29.01.2020).

15. Veselov A. V. [Modernization of the loadmeasuring device on the test benches of liquid rocket engines]. Reshetnevskie chteniya : materialy XXII Mezhdunar. nauch. konf. (12-16 noyabrya 2018, g. Krasnoyarsk) $v 2 \mathrm{ch}$. [International science and research conference (in memory of the Mikhail Fedorovich Redhetnev, general constructor of spase vehicles and rocket systems)]. Krasnoyarsk, 2018, P. 198-200.

\section{Библиографические ссылки}

1. Яцуненко В. Г., Назаров В. П., Коломенцев А. И. Стендовые испытания жидкостных ракетных двигателей / Сиб. гос. аэрокосмич. ун-т ; Моск. авиац. ин-т. Красноярск, 2016. 248 с.

2. Испытание и обеспечение надежности / А. И. Коломенцев, М. В. Краев, В. П. Назаров и др. ; Сиб. гос. аэрокосмич. ун-т ; Моск. авиац. ин-т. Красноярск, 2006. $336 \mathrm{c}$

3. Основы теории и расчета жидкостных ракетных двигателей / А. П Васильев, В. М. Кудрявцев, В. А. Кузнецов и др. М. : Высш. школа, 1983. 703 с.

4. Методология экспериментальной отработки ЖРД и ДУ, основы проведения испытаний и устройства испытательных стендов : монография / А. Г. Галеев, В. Н. Иванов, А. В. Катенин и др. Киров : МЦНИП, 2015. 436 с.

5. Испытание жидкостных ракетных двигателей / А. Е. Жуковский, В. С. Кондрусев, В. Я. Левин и др. М. : Машиностроение, 1981. 199 с.

6. Расчетный анализ прочности силоизмерительного устройства стенда для испытаний ЖРД с тягой 1000 тс / А. Н. Лошкарев, Д. В. Мерзляков, А. Е. Милов и др. // Труды НПО Энергомаш им. академика В. П. Глушко. 2012. № 29. С. 311-327.

7. Development of test stand for experimental investigation of chemical and physical phenomena in Liquid Rocket engine / E. A.Santos, W. F.Alves, A. N. A. Prado et al. // Journal of Aerospace Technology and Management. 2011. P. 159-170. Doi: 10.5028/jatm.2011.03021111.

8. Конструкция и отработка РДТТ / А. М. Виницкий, В. Т. Волков, И. Г. Волковицкий и др. М. : Машиностроение, 1980. С. 98-106.

9. Пат. 2225527 Российская федерация, F 02 K 9/96. Стенд для измерения тяги ракетного двигателя / Большаков А. Н., Завальнюк А. Г. № 2002114953/06 ; заявл. 05.06.2002; опубл. 10.03.2004.

10. Эткин Л. Г. Виброчастотные датчики. Теория и практика. М. : Изд-во МГТУ им. Н. Э. Баумана, 2004. $408 \mathrm{c}$.

11. Виноградов В. А., Валов В. И. Особенности подготовки и проведения огневых и холодных испытаний жидкостных ракетных двигателей на Химическом заводе - филиале ОАО «Красмаш» // Решетневские чтения : материалы XIII Междунар. науч. конф. (10-12 ноября 2009, г. Красноярск) : в 2 ч. / под общ. ред. Ю. Ю. Логинова ; Сиб. гос. аэрокосмич. ун-т. Красноярск, 2009. С. 102-103.

12. SKF compact inverted roller screw [Электронный pecypc]. URL: https://www.skf.com/binary/77-68546/ 10592-EN_compact-inverted-roller-screw.pdf (дата обращения: 29.01.2020).

13. Ряховский О. А., Воробьев А. Н., Марохин А. С. Планетарный ролико-винтовой механизм преобразования вращательного движения в поступательное, выполненный по «перевернутой» схеме // Известия высших учебных заведений. 2013. № 9. С. 44-48.

14. Научно-производственное предприятие «MEPA» [Электронный ресурс]. URL: http://nppmera.ru/ npp-mera-peredovyie-resheniya-dlya-staticheskix-ispyitanij (дата обращения: 29.01.2020).

15. Веселов А. В. Модернизация тягоизмерительного устройства на испытательных стендах жидкостных ракетных двигателей // Решетневские чтения : материалы XXII Междунар. науч. практ. конф. (12-16 ноября 2018, г. Красноярск) : в 2 ч. / под общ. ред. Ю. Ю. Логинова ; СибГУ им. М. Ф. Решетнева. Красноярск, 2018. С. 198-200.

(c) Begishev A. M., Zhuravlev V. Y., Torgashin A. S., 2020

\footnotetext{
Begishev Aleksey Mikhaylovich - graduate student; Reshetnev Siberian State University of Science and Technology. E-mail: alex-beg95@mail.ru.

Zhuravlev Viktor Yur'yevich - Cand. Sc., Professor; Reshetnev Siberian State University of Science and Technology. E-mail: vz@sibsau.ru.

Torgashin Anatoliy Sergeevich - graduate student; Reshetnev Siberian State University of Science and Technology. E-mail: ttarg23@gmail.com.
}

Бегишев Алексей Михайлович - аспирант; Сибирский государственный университет науки и технологий имени академика М. Ф. Решетнева. E-mail: alex-beg95@mail.ru.

Журавлев Виктор Юрьевич - кандидат технических наук, профессор кафедры двигателей летательных аппаратов; Сибирский государственный университет науки и технологий имени академика М. Ф. Решетнева. E-mail:vz@sibsau.ru.

Торгашин Анатолий Сергеевич - аспирант; Сибирский государственный университет науки и технологий имени академика М. Ф. Решетнева. E-mail: ttarg23@gmail.com. 